\title{
Pengaruh Biaya Promosi dan Harga Jual Terhadap Volume Penjualan Motor Yamaha Mio Soul Pada PT. Thamrin Brathers Lahat
}

\author{
Indra Hartini \\ Sekolah Tinggi IImu Ekonomi Serelo Lahat, indrahartini164@gmail.com
}

\begin{abstract}
ABSTRAK
Penelitian ini bertujuan untuk mengetahui seberapa besar pengaruhBiaya Promosi dan Harga Jual Dalam Meningkatkan Volume Penjualan Sepeda Motor Mio Soul Pada PT Thamrin Brathers Lahat. Rancangan penelitian yang digunakan dalam penelitian ini adalah penelitian Asosiatif / Kuantitatif.Populasi dalam penelitian ini adalah sejumlah data dari PT Thamrin Brathers Lahat. Sampel yang digunakan dalam penelitian ini adalah biaya promosi, harga jual dan kegiatan penjualan selama 5 (lima) tahun terakhir yaitu dari tahun $2015 \mathrm{~s} / \mathrm{d}$ tahun 2019. Hasil penelitian pada uji t, pengaruh variabel biaya promositerhadap volume penjualan menunjukkan ada pengaruh yang signifikan, pada variabel harga jual terhadap volume penjualan tidak ada pengaruh yang signifikan. Sedangkan uji secara simultan diperoleh nilai taraf signifikan $F=0,038$. Sehingga $F_{\text {hitung }}=$ $25,051>\mathrm{F}_{\text {tabel }}=5,41$ menunjukkan bahwa variabel biaya promosi dan harga jual, keduanya berpengaruh signifikan terhadap volume penjualan pada PT Thamrin Brathers Lahat, dengan taraf signifikan $\alpha=0,05$
\end{abstract}

Kata Kunci : Biaya Promosi, Harga Jual dan Volume Penjualan

\begin{abstract}
This study aims to determine how much the influence of promotion costs and selling prices in increasing the sales volume of Mio Soul motorbikes at PT Thamrin Brathers Lahat. The research design used in this research is associative / quantitative research. The population in this study is a number of data from PT Thamrin Brathers Lahat. The sample used in this research is promotional costs, selling prices and sales activities for the last 5 (five) years, from 2015 to 2019. The results of the research on the $t$ test, the influence of the variable promotional costs on sales volume shows that there is a significant effect. , there is no significant effect on the variable selling price on sales volume. While the test simultaneously obtained a significant level of $F=0.038$. So that Fcount $=25.051>$ Ftable $=5.41$ shows that the variable promotion costs and selling price, both of which have a significant effect on sales volume at PT Thamrin Brathers Lahat, with a significant level
\end{abstract}

Keywords: Promotion Costs, Selling Prices and Sales Volume

\section{A. PENDAHULUAN}

Kemajuan teknologi mendorong perkembangan bisnis otomotif yang semakin pesat. Hal ini ditandai dengan banyaknya dealer-dealer sepeda motor baru yang muncul di Indonesia. Adanya impor sepeda motor di Indonesia juga merupakan salah satu bentuk perkembangan bisnis otomotif di Indonesia sehingga menuntut perusahaan untuk melakukan persaingan yang sangat ketat. Untuk dapat terus bertahan perusahaan dituntut untuk melakukan strategi bauran pemasaran dengan baik. Kegiatan pemasaran dapat diartikan sebagai kegiatan manusia yang berlangsung dalam kaitannya dengan pasar.

Perkembangan

dibidang perekonomian selama ini telah banyak membawa akibat yang cukup pesat dalam dunia usaha, sehubungan dengan itu banyak perusahaan baru 
berdiri dan kembalinya perusahaan yang direhabilitasi, maka berakibat timbulnya persaingan yang ketat diantara perusahaan-perusahaan tersebut. Baik itu persaingan antar perusahaan sejenis maupun perusahaan yang tidak sejenis. Perusahaan dalam keberadaannya sebagai unit organisasi, pada umumnya didirikan dengan tujuan untuk memperoleh keuntungan dengan jalan menyediakan barang atau jasa yang sesuai dengan kebutuhan masyarakat. Keuntungan bias diperoleh apabila perusahaan dapat mencapai volume penjualan yang maksimal. Penetapan harga yang sudah bersaing di pasar merupakan salahsatu usaha perusahaan untuk dapat mengembangkan perusahaanya agar dapat meningkatkan volume penjualan dan laba yang di terima.

Volume penjualan merupakan salah satu faktor penentu yang sangat berpengaruh terhadap pencapaian laba bersih, sedangkan keuntungan atau laba merupakan sarana yang penting bagi kelangsungan hidup suatu perusahaan, maka dari itu perusahaan harus berusaha untuk menciptakan volume penjualan yang menguntungkan. Mengingat semakin ketatnya persaingan dalam bisnis dan kondisi perekonomian yang tidak menguntungkan, memaksakan para pengusaha untuk selalu giat berusaha agar perusahaan dapat tetap menghasilkan laba yang maksimal, sehigga membantu perkembangan usahanya. Salah satu usaha yang dapat menunjang kelangsungan hidup perusahaan adalah dengan cara menentukan harga jual.

Dalam kenyataan tingkat harga terjadi dipengaruhi oleh beberapa faktor yang antara lain meliputi kondisi perekonomian, penawaran dan permintaan, elastisitas permintaan, biaya, tujuan manajer, persaingan.
Harga suatu barang merupakan penentu bagi pemintaan pasar. Oleh karena itu, harga dapat dipengaruhi oleh luasnya pangsa pasar atau besarnya volume penjualan dari produk yang dihasilkannya. Bagi suatu perusahaan harga tersebut merupakan pendapatan bersih dan juga merupakan keuntungan bersih. Penentuan harga jual produk merupakan cara yang harus dilakukan pimpinan dengan berbagai cara atau metode, yang kesemuanya bertujuan agar produk-produk yang dipasarkan dapat dengan mudah disukai dan diterima oleh konsumen atau pembeli. Faktor lain yang sangat berpengaruh dengan volume penjualan adalah biaya promosi, karena melalui biaya promosi perusahaan menempatkan variabelvariabel promosi agar produk perusahaan dapat dikenal oleh masyarakat dan bahkan menimbulkan permintaan. Semakin besar biaya promosi yang dikeluarkan perusahaan, makasemakin besar pula volume penjualan yang dicapai oleh perusahaan.

Faktor-faktor yang mempengaruhi volume penjualan adalah harga jual, harga jual merupakan hal-hal yang sangat penting mempengaruhi penjualan atas barang dan jasa yang dihasilkan. Faktor lain yang berpengaruh dengan volume penjualan adalah biaya promosi, dalam kegiatan pemasaran promosi sangat perlu dilakukan oleh perusahaan untuk membujuk konsumen agar tertarik pada produk yang ditawarkan agar dapat meningkatkan volume penjualan.

Kegiatan promosi yang dilakukan oleh suatu perusahaan, pada dasarnya diharapkan dapat membuat penjualan menjadi meningkat. Jumlah dana yang tersedia merupakan factor penting yang mempengaruhi keberhasilan suatu promosi. PT Thamrin Brathers merupakan PT yang bergerak dibidang 
pemasaran produk yamaha yang sudah cukup terkenal dikalangan masyarakat akan produknya. PT Thamrin Brathers ini memperkenalkan produknya melalui iklan disurat kabar, radio maupun melalui sales.
Berikut ini daftar tabel Biaya Promosidan Harga Jual Terhadap Volume Penjualan pada tahun 2015 sampai dengan tahun 2019.

Tabel Data Biaya Promosi dan Harga Jual Terhadap Volume Penjualan Sepeda Motor Mio Soul Pada PT Thamrin Brathers Lahat Tahun 2015 s/d 2019

\begin{tabular}{|c|c|c|c|}
\hline Tahun & $\begin{array}{c}\text { Biaya Promosi } \\
(\mathrm{Rp})\end{array}$ & Harga Jual (Rp) & $\begin{array}{c}\text { Volume Penjualan } \\
\text { (Unit) }\end{array}$ \\
\hline 2011 & 4250000 & 15500000 & 36 \\
\hline 2012 & 5000000 & 12750000 & 34 \\
\hline 2013 & 6450000 & 14050000 & 37 \\
\hline 2014 & 7650000 & 14450000 & 42 \\
\hline 2015 & 8450000 & 14650000 & 44 \\
\hline
\end{tabular}

Sumber : PT Thamrin Brathers Lahat, 2020

Tabel diatas menunjukkan bahwa biaya promosi dan harga jual yang dilakukan oleh PT Thamrin Brathers Lahat berpengaruh pada volume penjualan yang ada. Dari tahun ke tahun, dapat kita lihat terdapat peningkatan maupun penurunan. Penurunan terjadi pada tahun 2012 dikarenakan banyaknya persaingan berbagai jenis produk motor, namun pada tahun 2013 mengalami peningkatan kembali, hal ini dikarenakan banyaknya jenis periklanan tentang produk tersebut, dengan demikian banyak konsumen yang berminat menggunakan produk tersebut hingga sekarang.

\section{B. KAJIAN TEORI}

\section{1) Volume Penjualan}

Volume penjualan menurut Budidharmo (2010:646), yaitu total penjualan yang didapat dari komoditas yang diperdagangkan dalam suatu masa tertentu.

Volume penjulan merupakan hasil dari kegiatan penjualan yang dilakukan perusahaan dalam usahanya mencapai sasaran yaitu memaksimalkan laba, (Oktariansyah, 2016:74).
Sedangkan dalam volume penjualan menurut pendapat yang dikemukakan oleh Abdullah (2011:444), menyatakan jumlah unit yang terjual dari unit produksi suatu pemindahan dari pihak produsen ke pihak konsumen, dan tetap pada suatu periode tertentu.

\section{2) Tujuan Volume Penjualan}

Tujuan manajemen penjualan secara umum yang biasanya ditetapkan oleh perusahaan sebagai berikut (Sudarsono, 2013:94)

a. Mencapai volume penjualan tertentu, Secara sederhana perusahaan akan menghitung pada tingkat penjualan tertentu perusahaan mencapai titik impas dan selanjutnya mendapat keuntungan.

b. Memperoleh laba keuntungan yang merupakan persyaratan ekonomi tersebut untuk mencapai pengembangan investasi.

c. Menunjang pertumbuhan perusahaan, Puncak tujuan karena setiap perusahaan menginginkan perkembangan perusahaan berupa peningkatan peningkatan kekayaan dan 
pengembangan usaha dibidang lainnya.

\section{3) Biaya Promosi}

Biaya promosi menurut Mulyadi (2010:69) Biaya promosi adalah biaya yang meliputi semua hal dalam rangka pelaksanaan kegiatan promosi atau kegiatan untuk menjual produk perusahaan baik berupa barang atau jasa pada pembeli sampai pengumpulan piutang menjadi kas.

\section{4) Harga Jual}

Harga jual ditetapkan oleh pembeli dan penjual dalam suatu proses tawar menawar. Penjual akan meminta harga jual yang lebih tinggi dari yang diharapkan akan diterimanya, sedangkan pembeli akan menawar lebih rendah dari yang diharapkan akan dibayarnya. Dengan tawar menawar mereka akan sampai pada suatu kesepakatan tentang harga (Fatya, 2010:92). Harga adalah jumlah uang (ditambah beberapa produk kalau mungkin) yang dibutuhkan untuk mendapatkan sejumlah kombinasi dari produk dan pelayanannya (Swastha, 2009:213).

\section{5) Keterkaitan Biaya Promosi dan Harga Jual Terhadap Volume Penjualan}

Biaya promosi sangat penting dalam meningkatkan volume penjualan, karena melalui biaya promosi perusahaan menempatkan variabel-variabel promosi agar produk perusahaan dapat dikenal oleh masyarakat dan bahkan menimbulkan permintaan. Semakin besar biaya promosi yang dikeluarkan perusahaan, maka semakin besar pula volume penjualan yang dicapai oleh perusahaan.

Harga jual merupakan hal-hal yang sangat penting dan mempengaruhi penjualan atas barang atau jasa yang dihasilkan penetapan harga yang sudah bersaing di pasar merupakan salah satu usaha perusahaan untuk dapat mengembangkan perusahaanya agar dapat meningkatkan volume penjualan dan laba yang di terima.Bila harga yang di tawarkan sudah bersaing di pasaran maka konsumen akan melihat pada barang atau produk yang di berikan apakah telah sesuai dengan harga yang di tawarkan dengan kondisi barang yang ditawarkan tersebut harus memiliki kualitas yang baik agar konsumen mempunyai pilihan dalam membeli sehingga tidak perlu mencari produk yang lain

\section{6) Kerangka Pemikiran}

Sebagai pedoman menganalisa dan membahas rumusan masalah penelitian skripsi yang bertujuan hubungan antara variabel-variabel yang di teliti, maka ditetapkan kerangka analisa penelitian sebagai berikut

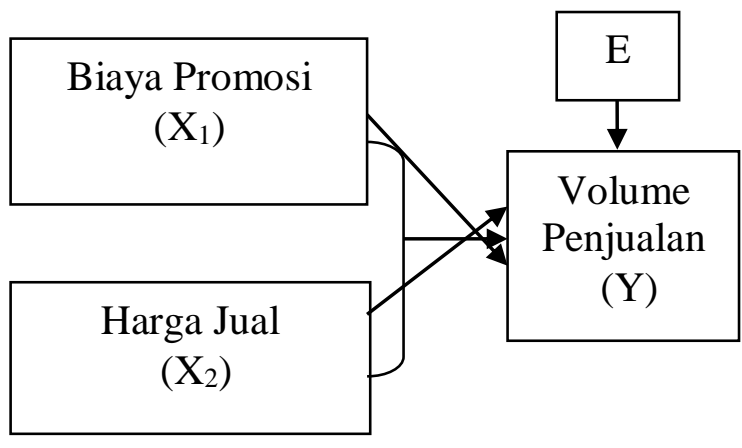

Keterangan :

Kerangka diatas dapat dijelaskan bahwa antara Biaya promosi $\left(\mathrm{X}_{1}\right)$, Harga Jual $\left(X_{2}\right)$ dan Volume penjualan (Y) mempunyai hubungan yang dapat dipisahkan artinya Biaya promosi dan Harga Jual dapat berpengaruh positif dalam meningkatkan volume penjualan. Semakin baik Biaya promosi dan Harga yang diberikan maka kepuasan volume penjualan akan meningkat. 


\section{7) Hipotesis}

Adapun Hipotesis yang penulis ambil :

1. Biaya promosi dan harga jual secara bersama-sama (simultan) berpengaruh signifikan dalam Meningkatkan Volume Penjualan Sepeda Motor Mio Soul pada PT Thamrin Brathers Lahat

2. Biaya Promosi berpengaruh signifikan dalam Meningkatkan Volume Penjualan Sepeda Motor Mio Soul pada PT Thamrin Brathers Lahat

3. Harga jual berpengaruh signifikan dalam Meningkatkan Volume Penjualan Sepeda Motor Mio Soul pada PT Thamrin Brathers Lahat

\section{METODE PENELITIAN}

Dalam penelitian ini peneliti menggunakan jenis penelitian deskriptif dengan pendekatan kuantitatif pada dasarnya dapat digunakan dari salah satu metodemetode yang ada. Populasi dalam penelitian ini adalah sejumlah data dari PT Thamrin Brathers Lahat. Sampel yang digunakan dalam penelitian ini adalah biaya promosi, harga jual dan kegiatan penjualan selama 5 (lima) tahun terakhir yaitu dari tahun $2015 \mathrm{~s} / \mathrm{d}$ tahun 2019. Tehnik pengambilan sampel menggunakan tehnik non probability sampling yang digunakan penulis dalam penelitian ini yaitu sampling purposive. Samping purposive adalah tehnik penentuan sampel dengan pertimbangan tertentu. Datanya secara Time Series yaitu merupakan sekumpulan data dari suatu fenomena tertentu yang didapat dalam beberapa interval waktu tertentu. Sampel yang diambil yaitu data biaya promosi, harga jual dan volume penjualan selama 5 tahun terakhir di mulai tahun 2015 sampai dengan 2019.

\section{PEMBAHASAN}

Hasil penelitian berdasarkan analisis kuantitatif menunjukan :

\section{Uji Normalitas}

Uji normalitas dilakukan untuk mengetahui apakah variabel yang dianalisis memenuhi kriteria sebaran normal atau berdistribusi normal. Berdasarkan hasil analisis dengan SPSS, maka dapat ditunjukkan hasilnya sebagaimana terlihat pada gambar berikut :

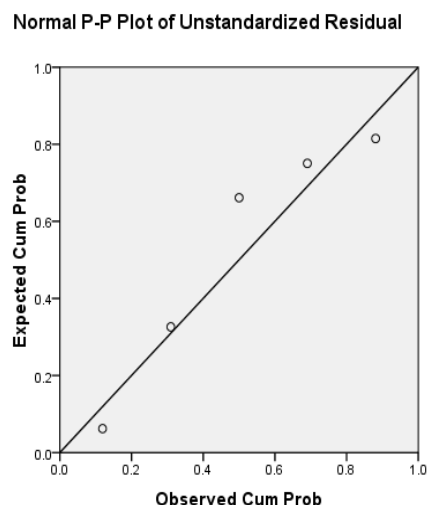

Sumber : Hasil Pengolahan data SPSS

Data yang berdistribusi normal dalam suatu model regresi dapat dilihat pada grafik P-P plot, dimana bila titik-titik yang menyebar disekitar garis diagonal serta penyebarannya mengikuti arah garis diagonal.Dari gambar tersebut terlihat bahwa hampir semua titik-titik mendekati garis diagonal, hal ini berarti bahwa data yang terkumpul kemudian dimasukan kedalam model garis regresi untuk dianalisis telah berdistribusi normal.

\section{Uji Multikolinieritas}

Hasil uji Multikolinieritas dari (variabel biaya promosi, harga jual) tidak ada yang memiliki VIF yang lebih besar dari 10 maka dapat disimpulkan bahwa data regresi yang akan digunakan tidak memiliki persoalan Multikolinieritas. 


\section{Uji Heteroskedastisitas}

Uji heteroskedastisitas dengan metode Glejser ternyata dalam model tidak ada persoalan,penelitian ini tidak terjadi heteroskedastisitas karena $p$ - value $>0,05$. Dengan demikian semua variabel independen memiliki varians yang konstan (sama) penyebarannya dan tidak mengalami masalah heteroskedastisitas.

\section{Analisis Regresi Berganda}

\section{Coefficients $^{\mathrm{a}}$}

\begin{tabular}{|l|r|r|c|r|r|}
\hline \multirow{2}{*}{ Model } & \multicolumn{2}{|c|}{$\begin{array}{c}\text { Unstandardized } \\
\text { Coefficients }\end{array}$} & $\begin{array}{c}\text { Standardized } \\
\text { Coefficients }\end{array}$ & & \multirow{2}{*}{ Sig. } \\
\cline { 2 - 5 } & \multicolumn{1}{c|}{$\mathrm{B}$} & Std. Error & Beta & \multicolumn{1}{c|}{$\mathrm{t}$} & \multicolumn{1}{c|}{ Sis3 } \\
\hline 1 (Constant) & 4.512 & 8.458 & & .533 & .647 \\
Biayapromosi & 2.154 & .000 & .897 & 6.459 & .023 \\
Hargajual & 1.428 & .000 & .340 & 2.452 & .134 \\
\hline
\end{tabular}

a. Dependent Variable: Volumepenjualan

\section{Sumber : Data diolah dari lampiran}

Berdasarkan hasil analisis data seperti yang telah disajikan pada tabel diatas, persamaan regresi yang didapat adalah :

$Y=4,512+2,154 X_{1}+1,428 X_{2}$. Berarti bila tanpa adanya variabel biaya promosi $\left(\mathrm{X}_{1}\right)$ dan harga jual $\left(\mathrm{X}_{2}\right)$, maka mempunyai volume penjualan sebesar $4,51.2$

- Nilai koefisien 4,512 menunjukkan dengan adanya biaya promosi $\left(\mathrm{X}_{1}\right)$ dan harga jual $\left(X_{2}\right)$ maka besarnya volume penjualan sebesar 4,512.

- Nilai koefisien $+2,154$, Tanda (+) menunjukkan hubungan biaya promosi dengan volume penjualan adalah positif, atau jika variabel biaya promosi $\left(\mathrm{X}_{1}\right)$ dinaikkan sebesar $1 \%$ sementara variabel harga jual $\left(\mathrm{X}_{2}\right)$ konstan maka volume penjualan akan naik sebesar $215,4 \%$
- Nilai koefisien $+1,428$ Tanda $(+)$ menunjukkan hubungan harga jual dengan volume penjualan adalah positif, atau jika variabel harga jual $\left(X_{2}\right)$ dinaikan sebesar $1 \%$ sementara variabel biaya promosi $\left(X_{1}\right)$ konstan, maka volume penjualan naik sebesar $142,8 \%$

\section{Uji F}

Analisis varians digunakan untuk melihat sumber-sumber variansi (keragaman) pada data penelitian.Secara statistik setidaknya ini dapat diukur dari nilai koefisien determinasi $\left(R^{2}\right), \quad$ nilaistatistik $F$ danstatistik t.

Untuk melihat pengaruh variabel bebas secara bersama-sama terhadap variabel terikat (kepuasan nasabah) digunakan uji F. Output ANOVA ditampilkan pada tabel berikut : 


\section{Analisis Varians}

ANOVAb

\begin{tabular}{|l|r|r|r|r|l|}
\hline Model & \multicolumn{1}{|c|}{$\begin{array}{c}\text { Sum of } \\
\text { Squares }\end{array}$} & df & $\begin{array}{c}\text { Mean } \\
\text { Square }\end{array}$ & F & Sig. \\
\hline 1 Regression & 68.467 & 2 & 24.233 & 25.051 & 0.38 \\
Residual & 2.733 & 2 & 1.367 & & \\
Total & 71.200 & 4 & & & \\
\hline
\end{tabular}

a. Predictors: (Constant), Harga jual, Biaya promosi

b. Dependent Variable: Volume penjualan

Sumber : Hasil Pengolahan data SPSS

Pengujian untuk melihat pengaruh variabel biaya promosi dan harga jual terhadap volume penjualan pada PT Thamrin Brathers Lahat. menghasilkan nilai $F_{\text {hitung }} 25,051$ dan $F_{\text {tabel }}(\alpha=0,05)$ pada $(n-2=3)$ adalah 5,41 dan nilai taraf signifikan $F=$ 0,038 . Sehingga $F_{\text {hitung }}=25,051>F_{\text {tabel }}$ $=5,41$. Berdasarkan hasil ini maka diputuskan untuk menolak $\mathrm{H}_{\mathrm{o}}$ dan menerima $\mathrm{H}_{1}$. Jadi variabel biaya promosi dan harga jual, keduanya secara simultan berpengaruh signifikan terhadap volume penjualan pada PT Thamrin Brathers Lahat, dengan taraf signifikan $\alpha=0,05$

\section{Uji Parsial (t)}

a. Pengujian pengaruh variabel biaya promosi $\left(\mathrm{X}_{1}\right)$ terhadap volume penjualan pada PT Thamrin Brathers Lahat.

Hipotesis

$\mathrm{H}_{\mathrm{O}}: \beta_{1}=0 ; \mathrm{t}_{\text {hitung }}<\mathrm{t}_{\text {tabel }}$ atau $\left(\mathrm{P}_{\text {value }}>0,05\right)$, maka $\mathrm{H}_{\mathrm{O}}$ diterima dan $\mathrm{H}_{\mathrm{i}}$ ditolak. Hal ini berarti bahwa tidak ada pengaruh yang signifikan dari biaya promosi $\left(\mathrm{X}_{1}\right)$ secara parsial terhadap volume penjualan $(\mathrm{Y})$.

$\mathrm{H}_{\mathrm{i}}: \beta_{1} \neq 0 ; \mathrm{t}_{\text {hitung }} \geq \mathrm{t}_{\text {tabel }}$ atau $\left(\mathrm{P}_{\text {value }}<0,05\right)$ maka $\mathrm{H}_{\mathrm{o}}$ ditolak dan $\mathrm{H}_{1}$ diterima. Hal ini berarti bahwa ada pengaruh yang signifikan dari biaya promosi $\left(\mathrm{X}_{1}\right)$ secara parsial terhadap volume penjualan (Y).

$>$ Analisa dan Kesimpulan

Nilai thitungbiaya promosi $\left(\mathrm{X}_{1}\right)$ sebesar 6,459 dengan tingkat signifikan sebesar 0,023 ( $P_{\text {value }}<$ 0,05), maka $\mathrm{H}_{\mathrm{o}}$ ditolak dan $\mathrm{H}_{1}$ diterima, berarti ada pengaruh yang signifikan dari variabel biaya promosi $\left(X_{1}\right)$ terhadap volume penjualan pada $\mathrm{PT}$ Thamrin Brathers Lahat.

b. Pengujian pengaruh variabel harga jual $\left(\mathrm{X}_{2}\right)$ terhadap volume penjualan pada $\mathrm{PT}$ Thamrin Brathers Lahat.

$>$ Hipotesis

$\mathrm{H}_{\mathrm{O}}: \beta_{2}=0$; $\mathrm{t}_{\text {hitung }}<\mathrm{t}_{\text {tabel }}$ atau $\left(P_{\text {value }}>0,05\right)$, maka $\mathrm{H}_{\mathrm{O}}$ diterima dan $\mathrm{H}_{\mathrm{i}}$ ditolak. Hal ini berarti bahwa tidak ada pengaruh yang signifikan dari harga jual $\left(\mathrm{X}_{2}\right)$ secara parsial terhadap volume penjualan $(\mathrm{Y})$.

$\mathrm{H}_{\mathrm{i}}: \beta_{2} \neq 0 ; t_{\text {hitung }} \geq \mathrm{t}_{\text {tabel }}$ atau $\left(P_{\text {value }}<0,05\right)$ maka $\mathrm{H}_{\mathrm{o}}$ ditolak dan $\mathrm{H}_{1}$ diterima. Hal ini berarti bahwa ada pengaruh yang signifikan dari harga jual $\left(\mathrm{X}_{2}\right)$ secara parsial terhadap volume penjualan (Y).

$>$ Analisa dan Kesimpulan

Nilai thitung $\left(\mathrm{X}_{2}\right)$ sebesar 2,452 dengan tingkat signifikan sebesar $0,134\left(P_{\text {value }}>0,05\right)$, maka $\mathrm{H}_{\mathrm{o}}$ 
diterima dan $\mathrm{H}_{1}$ ditolak, berarti tidak ada pengaruh yang signifikan dari variabel harga jual $\left(\mathrm{X}_{2}\right)$ terhadap volume penjualan pada PT Thamrin Brathers Lahat.

\section{F. KESIMPULAN}

Berdasarkan analisis hasil penelitian mengenai beberapa faktor yang mempengaruhi volune penjualan pada PT Thamrin Brathers Lahat dapat ditarik kesimpulan sebagai berikut :

1) Hasil penelitian ini diperoleh bahwa Biaya Promosi dan Harga Jual berpengaruh secara simultan terhadap volume penjualan Sepeda Motor Mio Soul pada PT Thamrin Brathers Lahat

2) Biaya promosi berpengaruh secara parsial terhadap volume penjualan Sepeda Motor Mio Soul pada PT Thamrin Brathers Lahat

3) Harga jual tidak berpengaruh secara parsial terhadap volume penjualan Sepeda Motor Mio Soul pada PT Thamrin Brathers Lahat

4) Hasil analisis regresi berganda mendapatkan nilai koefisien korelasi ganda (R) sebesar 0,981, maka dapat disimpulkan bahwa biaya promosi dan harga jual memiliki hubungan yang kuat dengan volume penjualan Sepeda Motor Mio Soul pada PT Thamrin Brathers Lahat

5) Besarnya koefisien Determinasi $\left(R^{2}\right)$ adalah 0,962. Artinya perubahan variasi volume penjualan pada PT Thamrin Brathers Lahat, dapat dijelaskan oleh variabel biaya promosi dan harga jual dengan kontribusi sebesar 96,2\% sedangkan sisanya sebesar $3,8 \%$ dapat dijelaskan oleh variabel lain yang tidak dimasukkan kedalam model ini.

\section{DAFTAR PUSTAKA}

Abdullah. 2011. Peranan Biaya Promosi Dalam Meningkatkan Volume penjualan (Studi Kasus Pada Salah Satu Perusahaan Pembiayaan di Palembang). Jurnal Ekonomi dan Informasi Akuntansi (Jenius). Vol. 1 No. 2 Mei 2011.

Basu Swastha, dan Irawan. 2009. Manajemen Pemasaran Moder (Edisi II, Get. VHI). Yogyakarta: Liberty Gitosudarmo. 2008. Manajemen Pemasaran. edisi kedua, cetakan keenam, Yogyakarta: BPFE.

Budidharmo. 2010. Volume Penjualan Suatu Produk. Penerbit: PT. Bumi Aksara, Jakarta.

Fatya. 2010. Peningkatan harga Jual. Yogyakarta: Andi

Mulyadi, 2010. Faktor-faktor yang mempengaruhi Permintaan dan Penawaran. Jakarta: Grasindo

Oktariansyah, 2016. Pengaruh Penetapan Harga Terhadap Volume Penjualan Besi Pada Pt. Inti Logam Palembang. Jurnal Media Wahana Ekonomika Vol.13 No.2 Juli, 2016, Hal: 6882.

Sudarsono. 2013. Manajemen Pemasaran. Cetakan Ke V. Erlangga, Jakarta. 